\title{
Lendawi: The Multifunction Chants and Their Metaphorical Expressions Among The Lany Tribe In Papua
}

\author{
Reimundus Raymond Fatubun ${ }^{1}$ \\ English Education Study Program, Cenderawasih University,Jayapura, Papua, Indonesia ${ }^{1}$ \\ \{ever59rayfat@gmail.com $\left.{ }^{1}\right\}$
}

\begin{abstract}
The Lany is a tribe in the mountains inhabiting the area, close to Wamena, formerly called West Dani. This tribe has a type of chants called lendawi that is chanted for a number of occasions. Ethnographic method was used to find the functions of the lendawi; for analysis of the metaphors, Halley's semantic field hierarchy was used. The study found that lendawi may be carried out anywhere anytime depending on certain functions. Seven functions were found: (1) for lamenting a dead person, (2) for thanking people contributing something in an event, (3) for remembering a family member who is already dead or in a foreign land, (4) for releasing a newly wed girl to follow her husband or a family member to go to a foreign land, (5) when meeting a person who resembles a family member already dead or far away, (6) when visiting a sick relative or friend, (7) for welcoming a relative or family member from overseas. The semantic field shown in the metaphorical expressions were found to be at the levels of (a) being e.g. sadness like in the landawi for the dead; (b) substance like clouds for eternity and rain for tears, (c) terrestrial like mountains and rivers, in the mention of mount Tari, and Donggi and Konda rivers, (d) living like weeds or grass in the mention of gardens, (e) animate like birds in the mention of the birds kimagi, welem, uluwe, prikokir, piage. The semantic field is more around the surrounding area or some other places but still in Papua as found in the metaphors.
\end{abstract}

Keywords: Lendawi; Chant; Metaphorical Expressions; Lany; Tribe; Papua

\section{Introduction}

\subsection{A Brief Overview of the Lany Socio-Cultural Background}

There are 7 Adat (Customary Laws) Regions in Papua: the Doberai region, the Boberai region, the Ha-Anim region, the Saireri region, the Mamta region, the Mi-Pago region, and the La-Pago region, and Lany belongs to the La-Pago in the moutains.

The Lanny inhabit the central mountain range plateau of Papua. They have become hunters and farmers since antiquity (Muller, 2008). They grow sweet potatoes, taros, bananas, sugar canes, various types of beans, and vegetables. Some of the inhabitants still use adzes, knife made from animal bones, and spears. Some still wear their traditional attires: sali from dried grass and yonggonoak from dried tree barks for women and girls, and koteka from dried gourd 
for men and boys. They may decorate themselves with white-black colors, and cassuary, chicken, and maleo bird feathers, as well as bracelets and rattan belts. They have traditional dances called wisisi and pesek that are performed, especially in adat rituals, to welcome guests like dignitaries or foreign tourists.

The Lany have a traditional musical instrument called luggik which is played by men when they are resting or having a break from work. They have a traditional net bag called noken, with a multifunction: for carrying garden produce, carrying babies, etc. Their traditional house is called onai, shaped like a mushroom, similar to the Dani's honai. Men's onai is called kunu and women's onai is called ome. The Lany have a number of rituals related to bride price delivery, head price, thank giving rituals for winning a tribal war, rituals to commemorate the deaths of ancestors, thanksgiving rituals for abundant harvest from new gardens, etc. Fingers cutting which is done to show sadness because of a family member's death: a husband, a wife, a father, a mother, a child, a brother, a sister, is disappearing because more and more people among the Lany are now educated and make use of their education to deconstruct cultural practices that bring disadvantages rather than advantages. For a marriage to be considered valid, three types of bride price have to be delivered: (1) wam (pigs), (2) noken (the net bags), (3) yebarip (money).

Studies done on this tribe are not many - let alone on lendawi. In 1993, there was a study on the phonology of West Dani (now Lany) Language by Purba et al in which I was a member, then in 1997, there was another a study on West Dani syntax also done by Purba et al. There has been only one study on lendawi in which I was involved and from which this article has been based on, that is, by Yikwa (2018) discussing the structure, types, and sociocultural values of lendawi.

\subsection{Oral Literature}

Oral literature, oral tradition, verbal folklore, folk literature, oral performance, popular culture - these areas of human communication and performance are now attracting increasing attention from social anthropologists (Finnegan, 1992). It is stated in Mourner and Rausch (1991:158) that oral literature is the ballads, folktales, and proverbs of preliterate or nonliterate cultures that are sung or recited to audiences and are passed with change from generation to generation through memory rather than by being written down. Common to oral literature are devices that aid memory, such as traditional phrases, repetition, and metrical patterns.

Since the oral literature is still literature except that it is oral, it also shares characteristics belonging to literature. Lendawi seems to belong to poetry since shares characteristics of poetry. The lendawi may be lyric or narrative The lyric expresses personal emotion in a "sing able" way or tuneful form. The emotion is personal, whether it arises from the individual's experience or the experience of others. The lyric stirs the emotions by its rhythm and imagery. The lyrical lendawi may be in the form of an ode, a simple lyric, a reflective lyric, or an elegy; the narrative lendawi may be an epic, a mock epic, a ballad, a metrical romance, a tale, an allegory, an idyll, or a descriptive poem.

\subsection{What is lendawi?}

This is a type of multifunction chants chanted by the Lany tribe. The lendawi is both individual and communal. Lendawi is a means of communicating with both the living and the dead, among people, between people and nature and the cosmos. Chanting is universal and not limited to a specific culture, language or historical moment. Older Lany people in the villages still chant the lendawi for the various occasions. The youth rarely practice or attend 
ceremonies where these lendawi are chanted any longer. Lendawi is an important part of Lany culture because there is a lot of oral data about the culture contained in the lendawi. Townsley (2001:267) argues that chants use a special language to recount the mythical foundations of reality and so "Chants are ... most highly prized possessions, the vehicles of ... powers and the repositories of ... knowledge". Descola (1986) also show that the metaphorical words of chants present a socialized conceptualization of nature. This is particularly the case in chants performed to secure the positive outcome of livelihood activities."

According to Townsley (2001) metaphorical language is needed to open up to a wider vision of reality which is instrumental for its mystical manipulation. Townsley argues that the metaphorical construction of chants is directly linked to the visions which accompany the chanting. Such a blending of the senses - in this case the fusion of auditory and visual fields is known as synaesthesia which is essential to tribal life, and is a cognitive phenomenon of cross-modal perception (Shanon 2002).

\section{Method}

The research method used in this study was ethnographic method, with 9 Lany people ranging in age from 40 to 80 years as sources of the data, the data were collected through interviews and recordings. For data analysis grounded theory was employed, and the data are presented in tables for the functions, then the metaphorical expressions were identified and the meanings were discussed. In this short article, only some representatives of data are presented.

The discussion will start with the explanations of the lendawi, their functions, and their formula, then the presentation of 6 samples of the lendawi are given here.

The explanation of the metaphorical expressions in the lendawi will be based on Halley's semantic field (in Chink, 1980:139-153, Wahab, 1991:78). Halley puts forth the semantic field of human perception in a hierarchy starting with being on top down to human at the bottom like the following: (1) being e.g. truth, beauty, (2) cosmos e.g. sun, moon, (3) energy e.g. light, wind, (4) substance e.g. hydrogen, anti-matter, (5) terrestrial e.g. mountain, river, (6) object e.g. minerals (rock), (7) living e.g. flora, (8) animate e.g. fauna, and (9) human e.g. man, girl, at the bottom is human. Wahab (1991:87) also mentions that the semantic field of perception is bound with two aspects: (1) physical environment e.g. fauna and flora, and (2) cultural experiences which consists of social, moral, belief, and arts.

\section{Findings}

Only some representatives of parts of the lendawi are given below from the 39 lendawi for each of the functions with some explanation about the occasions.

Lendawi \#1: for lamenting the dead

The lamentation lendawi below is for the death of a man lamented by another man. This is a situation in which the first man is lamenting on his friend, leaving his brothers and sisters. This lamentation expresses his unwillingness to let him go leaving them alone in Kurulu, with a lot of tears. It is therefore, this lendawi is a lamentation, precisely a eulogy.

\begin{tabular}{lllllllll}
\hline \multicolumn{4}{c}{ The Lendawi } & \multicolumn{5}{c}{ English translation } \\
\hline Nogoba Kagup kabok oo & ndugwi & paga & Sir, leaving your love, you will go \\
\hline
\end{tabular}




\begin{tabular}{ll}
\hline garu-garu nano nda, iiii. & peacefully to heaven, iiii. \\
Oopur tiatebek Tari abuna time kone gugur & Let your voice be carried by the wind \\
wiya wonok nagalowak ooo. & among the low clouds covering mount Tari \\
Nogoba wae kagalip loge yime kalir loge & Sir, weeds are left to grow thick in this \\
yinduak oooo. & place. \\
Nogobaooooo. Erigero oo. & Father... Sad, sad ... oo. \\
\hline
\end{tabular}

Lendawi \#2: for Thanking

Different from lendawi \#1, lendawi \#2 is not a eulogy. This lendawi is chanted to thank those who contributed something e.g. goods to an event or an activity. This event is usually an adat event or some other event envolving a number of people gathering.

\begin{tabular}{|c|c|}
\hline The Lendawi & $\begin{array}{c}\text { English translation } \\
\end{array}$ \\
\hline $\begin{array}{l}\text { Wone gok mbagwi nogo ap pagok ooo. } \\
\text { Ninaporemegwe nogo Gweage dirok wagao } \\
\text { oooo. } \\
\text { Wone gok mbagwi nogo inarugi pagaluk } \\
\text { ooo yi iiii. } \\
\text { Niyo Dogi konda dirok bambegak yelok } \\
\text { golok wagaoo ooo. } \\
\text { Erigerok aaaa. }\end{array}$ & $\begin{array}{l}\text { People talk much because others are } \\
\text { around. } \\
\text { Our relatives are coming past the Gweage } \\
\text { river. } \\
\text { Wone gok mbagwi nogo inarugi pagaluk } \\
\text { ooo yi iiii. } \\
\text { People are talking a lot because their } \\
\text { relatives support them. } \\
\text { Our relatives come through the tears of the } \\
\text { Dogi and the Konda. } \\
\text { Sad, sad. }\end{array}$ \\
\hline
\end{tabular}

Lendawi \#3: for Saying Goodbye

There are two lendawi given here: (a) lendawi chanted to say goodbye to a family member leaving for a foreign land, e.g to pursue a higher education; (b) a lendawi for parting with a just married girl to follow her husband to his place/village, usually the place is a bit too far. Usually advice is given to the family member leaving to pursue a higher education, for the newly married girl, memories of childhood of the girl through her adulthood is mentioned in the lendawi when the girl is leaving her village on her way with her husband. The following lendawi is chanted to say goodbye to a family member leaving for a foreign land.

\begin{tabular}{|c|c|}
\hline The Lendawi & English translation \\
\hline $\begin{array}{l}\text { Komologwe yinok wone gok mbagwi eee, } \\
\text { yimegwe nogome yi le eeeee. }\end{array}$ & $\begin{array}{l}\text { Because you look at the girls, you raise } \\
\text { your voice here, they are walking, crying. }\end{array}$ \\
\hline $\begin{array}{l}\text { Ap Dalek wae. Erek wae ninamegwe nogo } \\
\text { yi ooo. Eeeeeee. }\end{array}$ & $\begin{array}{l}\text { Dalek, Erek. Look we are going back to our } \\
\text { home. }\end{array}$ \\
\hline $\begin{array}{l}\text { Ninagalonak yaruk-yaruk le eеeеeе. } \\
\text { Erigerokoooo. }\end{array}$ & $\begin{array}{l}\text { The mothers holding their babies crying } \\
\text { sadly. Sad, sad. }\end{array}$ \\
\hline Ap piam-piam me oggo mbaguga eeeeee. & Sir, people are embracing one another .... \\
\hline $\begin{array}{l}\text { Ninamegwe yi. Eeaooo. Ap Tageme medek } \\
\text { erigerok. Aoooo. }\end{array}$ & $\begin{array}{l}\text { Towards our home. } \\
\text { Our mothers, crying from home. }\end{array}$ \\
\hline $\begin{array}{l}\text { Ninagalonak umegwe le eee ooo eeeee. } \\
\text { De wae eee. Ume undeme oo. Nore bonak } \\
\text { ninamegwe nogome. Leeeooooee. }\end{array}$ & $\begin{array}{l}\text { De passing in front of houses, passing in } \\
\text { front of your house, my friend. Sad. They } \\
\text { are crying sobbingly. }\end{array}$ \\
\hline $\begin{array}{l}\text { Ap kogoyanak-kogoyanak menganomgwe } \\
\text { ye. E towe Gin one. Eeeeeee. }\end{array}$ & $\begin{array}{l}\text { Sir, passing in front of the the Kogoyas' } \\
\text { place, there are the sounds chirping birds. }\end{array}$ \\
\hline $\begin{array}{l}\text { Umar wae e. Lea wa ee. Ninamegwe } \\
\text { nogome yi ooooooo. }\end{array}$ & $\begin{array}{l}\text { Umar. Lea. ...Look! They are passing } \\
\text { through our house. }\end{array}$ \\
\hline
\end{tabular}




\begin{tabular}{ll}
\hline Ap nawor wae Kelilagwe mili-milioo. & My brother, look at the green view of \\
Erigerok oaoooo Erigerok oaoo. & Kelila, sad, sad ... \\
Komologwe pagopinok me yiwone-ndiwone & Expecting the girls, you talk with sweet \\
pian-pian o. Eeeeeee. Ak agalo pian-pian & words, praising the sister with her mother \\
ninamegwe nogome towe Gin one. Eeeeee & passing our house listening to chirping of \\
Kogoya waee. Lugagwe managalogoner & birds. \\
oooo kir mongonom yi. Labura le oeeee. & $\begin{array}{l}\text { Hey Kogoya, look towards the direction of } \\
\text { Luga. Look at the snaking rivers while } \\
\text { crying. }\end{array}$ \\
\hline
\end{tabular}

(b) The following lendawi is chanted to say goodbye to a just married girl to follow her husband to his place/village, usually the place is a bit too far.

\begin{tabular}{|c|c|}
\hline The Lendawi & $\begin{array}{c}\text { English translation } \\
\end{array}$ \\
\hline $\begin{array}{l}\text { Nebibe kinamengwe logwe. } \\
\text { Kira golongwe time logome enabo wae } \\
\text { kagup logwe yagwa-ndagwa agan norak } \\
\text { kwe ra aaa. } \\
\text { Kelapa logwe awe yarir. Oooo.Tagu logwe } \\
\text { awe yarir oooo. Kota logwe time erigerok } \\
\text { negelogoner logwe eeee. } \\
\text { Nebibe Kira gologwe time lewak kane } \\
\text { mengenom. Ooo Yagwa ndagwa nawak } \\
\text { nduk logwe. } \\
\text { Nebi nak kwe yira taguga paga logwe time } \\
\text { Kelapa engga paga logwe time kabur logwe } \\
\text { indukwanduk oo. Kenara indukwanduk oo } \\
\text { Nebio oooo Timer mengenom logwe yime } \\
\text { Atep mengenom logwe yime pirikikur } \\
\text { egwak erigerok ariwanuklogwe. } \\
\text { Enabogwe wae kwe Urdina kwe Yarolina } \\
\text { inoba logwe arinagalogomigindik time ra } \\
\text { aa. Kawone logwe erugun ooo. } \\
\text { Enabogwe wae ooo. Kunik logwe worak } \\
\text { meden unde logwe lemeden erigerok igak } \\
\text { logwe. Ee iiii. Unde logwe lemeden ando } \\
\text { logwe lemeden. } \\
\text { Kwe Urdina logwe time kwe Yarolina } \\
\text { logwe time nenegen logwe pigigitik kwe } \\
\text { muka logwe lain ooooo. Ogoti ago logwe } \\
\text { lain ooo } \\
\text { Nawor kwe yira aaaaaa Aerigerok } \\
\text { logoner logwe. }\end{array}$ & $\begin{array}{l}\text { I cannot accept this reality. } \\
\text { You should live in the village of Kira, your } \\
\text { village. My youngest sister, cheer up in } \\
\text { happiness. } \\
\text { You will grow coconuts, you will plant } \\
\text { sago ... } \\
\text { When you are in a foreign land, in the city } \\
\text { there. } \\
\text { I am in Kira, the place of sorrow, disagree } \\
\text { The place where corpses will be burnt, } \\
\text { lamented. Shouts of goodbyes. } \\
\text { I do not agree, women from the place full } \\
\text { of sagu, the place full of coconuts there, } \\
\text { look out. } \\
\text { Sad, the dwelling place of Timer and Atep. } \\
\text { Listen to the sounds of a prikikur bird } \\
\text { bringing a message, remembering you. } \\
\text { My youngest sister, you will go to the place } \\
\text { of madam Urdina, madam Yarolina there } \\
\ldots \text { we over here will tell your story. } \\
\text { My youngest sister, if you were still here, } \\
\text { we can take care of one another, sad, sad ... } \\
\text { we can still take care of one another. } \\
\text { In the place of madam Urdina, in the place } \\
\text { of madam Yarolina. } \\
\text { My youngest sister ... we here lament, sad, } \\
\text { sad. }\end{array}$ \\
\hline
\end{tabular}

Lendawi \# 4: for Welcoming People

This lendawi is for welcoming a relative or family member from other foreign lands, etc. The following text is not a lamentation, but a welcome cry by a mother for a son who went to some foreign land and just arrived back in his village in Kelila. She is expressing how she longed for him and she believed that he would some day be back home. She is expressing that she would be angry with him in the past because she would not want him to be in trouble. Yikwanak is a call name for a boy/man whose mother is from the Yikwa tribe, one whose mother is from the Kogoya tribe is called Kogoyanak. Kogoyagwe is for a girl whose mother is from the Kogoya tribe. 
This following lendawi is by a mother who welcomes her son back home after having been in some foreign land. The mother is expressing how she longed for her son when he was away and that some day he would be back home.

\begin{tabular}{|c|c|}
\hline The Lendawi & English translation \\
\hline $\begin{array}{l}\text { Ap yikwa tabuni menganom mayu } \\
\text { logwe wagao. } \\
\text { Tari gologwe nio logwe ukwe oooo } \\
\text { erigerok } \\
\text { Ap Tabenak yi waee kiawe menganom } \\
\text { iriga logwe ukwe ooo. } \\
\text { Nio Balim ineri logwe towe logwe } \\
\text { onioneooo karigik kabuaooo. }\end{array}$ & $\begin{array}{l}\text { In the dwelling place of the Yikwa } \\
\text { Tabuni, rain is pouring down. } \\
\text { At the foot of mount Tari, water is } \\
\text { flowing, sad, sad. } \\
\text { Tabenak, in the dwelling place of your } \\
\text { uncles, weeds have grown thick. } \\
\text { Birds are chirping in the Balim water } \\
\text { spring, sad, sad. }\end{array}$ \\
\hline
\end{tabular}

Lendawi \# 5: for Remembering a Dead Person

The following lendawi is chanted when remembering a dead family member, e.g. a husband by a widow while taking a rest in the garden after hard work. This lendawi is chanted because there is nobody to help with the hard work in the garden.

\begin{tabular}{|c|c|}
\hline The Lendawi & English translation \\
\hline $\begin{array}{l}\text { Ap Pilipueee. Eee. Yikwanak waeeee } \\
\text { Eee. Ir Remanur inok oooo orenak oo } \\
\text { Eee neak be aaaeee. Ilime oo. } \\
\text { Kinalia liak layak time ooo. Kinarugi } \\
\text { logwe time. Kinom logwe logonip nda } \\
\text { oo. Iiieeiii. } \\
\text { Kogoyanak wae. Eo. Napur be. Eee } \\
\text { kinawi yogweme logwe yime. Ee. } \\
\text { Kudik logoner kundak logoner } \\
\text { yimegwe logwe woragun oo. } \\
\text { Ap Den. Waeeeee. Naor. Ebeeeeee. } \\
\text { Kane logwe urirak. Aaa Ogi logwe } \\
\text { worak aaaaa ooooo Uranur wonok } \\
\text { oooo. Panur. Onok. Inebelek yi age } \\
\text { eeee iiii }\end{array}$ & $\begin{array}{l}\text { Mr. Pilipur. Yikwanak } \\
\text { The child of Ir Remanur, the child of his } \\
\text { friend. My son in the dark place. } \\
\text { Stay together in the cradle in the place ... } \\
\text { together with your family } \\
\text { Kogoya's son, my child. In this place we } \\
\text { grieved while sitting here. We were } \\
\text { waiting for others to come. } \\
\text { Den, my brother, my little brother who } \\
\text { went to find fire woods, who went to find } \\
\text { hays and brought them back. Putting } \\
\text { them in the house but now no more. }\end{array}$ \\
\hline
\end{tabular}

Lendawi \# 6: When Meeting a Person Resembling a Family Member

The following lendawi is chanted to remember a family member or relative when meeting a person resembling the family member or the relative who is already dead or in some far away land. The lendawi is an example of this type which was chanted by a woman. The chanter would look towards the village, the mountains, the clouds to remember the family member or relative. 


\begin{tabular}{lll}
\hline \multicolumn{1}{c}{ The Lendawi } & \multicolumn{1}{c}{ English translation } \\
\hline Kuliga Yikwagwe yira kangik kabok & Hey, Yikwa girl, your story has been \\
logwe dugi wonok logwe waga ooo. & brought by clouds until our place. \\
Kiruwi kauri kagalume logwe logogun & We will stay among your brothers and \\
so. & $\begin{array}{l}\text { sisters. } \\
\text { Nio. Gweage dirok ugwa dirok kiawe } \\
\text { wonogo menganom towe kimagi one } \\
\text { erigerok. Oo. Ooo. }\end{array}$ & $\begin{array}{l}\text { and Ugwa flow rapidly .... Birds } \\
\text { chirping. }\end{array}$ \\
\hline
\end{tabular}

\section{Discussion}

\subsection{The Formula of the Lendawi}

Lendawi is chanted in the Lany community with similar formulas. Since quite a number of people would come to condole with the family members of the diseased, or for thanking contributors to an event, or saying goodbye to a newly wed girl, the formula of the lendawi for these occasions (functions number 1 through 4 ) is similar like the following: (a) a number of women or men would sit or be together and the lendawi would begin with a start: one of them would inhale a little and would start chanting one line. At the end of the line and the ends of any succeeding lines, the others will join in dividing their voices (e.g. bass, tenor, etc.) naturally. For the other kinds of occasions, the lendawi could be chanted by individuals, like in functions 5 through 8 .

\subsection{Functions of the Lendawi}

Lendawi may be said to be eulogies or soliloquies for the various occasions in laced language to some extent with metaphors. The chants are very lamenting but they are not always pathos of suffering. Expressions of grief may be found more in the lendawi for the dead or when remembering a family member when one is alone with hard work and nobody around to give a hand. This loneliness is described in the lendawi. The lendawi is therapeutic because grief find channel through the expressions in the lendawi. The different occasions are vividly expressed in the lendawi. The lendawi may be performed for various functions: (1) for lamenting a dead person; (2) for thanking people contributing something in an event, e.g. an adat event; (3) for saying goodbye to a newly wed girl to follow her husband, or a family member to go to a foreign land for certain purposes; (4) for welcoming a relative or family member from other foreign lands, etc., (5) for remembering a family member who is already dead or in a foreign land; (6) when meeting a person who resembles a family member already dead or far away; (7) for remembering a person in a foreign land when looking at his or her picture(s) at home; (8) for visiting a sick relative or friend. The lendawi contains metaphorical expressions related to geography, daily existence, ancestors, beliefs, cosmologies, etc.

\subsection{The Metaphorical Expressions in the Lendawi}

Hierarchical wise, in the Lany lendawi, one can see that most metaphorical expressions are found in the level of (a) being e.g. truth, beauty; (b) substance like clouds, rain, (c) terrestrial like mountains (mount Tari, Donggi and Konda rivers, (d) living like grass, (e) animate like birds (the birds kimagi, welem, uluwe, prikokir, piage). These metaphorical expressions are elaborated below as they are found in the lendawi context.

(1) From the level of being:

Wone gok mbagwi nogo inarugi pagaluk ooo yi iiii. 
People are talking a lot because their relatives support them.

(2) From the substance level: clouds and rain

(lendawi\#2)

a. Clouds (e.g. in lendawi \#3 and \#4). Clouds in most of the lendawi represent eternity. In the following quotes, for example, the memories of the father are kept in the clouds, that the mother is above the clouds, looking down on her child. Because there are clouds almost daily and that the clouds are always in the sky, the memories will always be there for good.

Nogoba, Kanggup kabok ooo ndugwi paga nggaru-nggaru nano ndaaa iiii...

Father, your memories, your story will be on the clouds.

(lendawi\#3)

Iii ... nagalo waeee ndugi paga loge nanunda...kena unagak nanuooo.

My mother.... is on the clouds looking down.

(lendawi\#4)

b. Rain (e.g. in lendawi \#2, \#10 and \#16). Rain in most of the lendawi represent tears. Since these lendawi are for lamenting the dead, rain is mentioned many times to represent the tears as the following quotes indicate.

Ap inamegwe Kurulu time mayu ooo erigerok.

Relative, brother, the rain is falling. It wets the people in Kurulu, dear.

(lendawi\#2)

Ooo, ap Wenda Pagawak mengganom mayu, niyo Gweage loge uke oo.

Ooo, rain falls in the Wenda Pagawak people's house, so there is flood in the Gweage river.

(lendawi \#10)

Nagalo, ap Yikwa Tabuni menganom mayu logwe waga, erigerok aa nagalo.

Mother the rain falling down in the place of YikwaTabuni, dear mother.

(lendawi \#16)

(3) From the terrestrial level: mountains, rivers (e.g Mount Tari, the rivers Dongi, Konda, and Gweage) in lendawi \#3, \#4, and \#6,). These mountain and rivers are many times mentioned in the chants. The Lany people mention mount Tari and the rivers in their chants because they believe that when they, particularly the Yikwanimbo clan and the Yikwakogoya clans, die, their spirits will go to live in the mountain or rivers for eternity. They also mention the rivers Dongi, Konda, and Gweage many times in the chants which seem to indicate similar meaning. These mountain and rivers represent eternity.

Yiii... Tabenak kone yugu nogo Tari abuna logwe logogin ooo.

Tabenak, your voice will live under Mount Tari.

(lendawi \# 3)

Eiye eiye ... nagalo waeee nio donggi... Konda ... ineri inera nanuo...

Hello my mother.....goes to Dongi and Konda river springs

(lendawi \# 4) 
Ap yira, kanggup kabok logwe, Gweage ndirok logwe logogin oo erigerok $o$.

Hello father, your story/ will live in Gweage river, sayangeee.

$$
\text { (lendawi \# 6) }
$$

(4) From the animate level: fauna (e.g. birds like kimagi, welem, uluwe, prikokir, and piage) found in lendawi \#5 and \#6. The Lany people believe that these birds are news bringers. The Lany living in Kelila particularly, believe that kimagi bird is the news bringer. If the bird, usually called eyonggame memdek, which means spirit from the forest, goes on chirping, this indicates that there is no problem. But if the bird is quiet, this means there may be problems coming. This bird lives in the cold area in the middle of the forest around Mount Tari.

Towe Kimagi one Uluwe one mban naruk kunungak mban logogin ooo... I hear the Kimagi bird tweet and Uluwe bird tweet continuously

(lendawi \# 5)

Kiawe wonogwemengwe towe Kimagi loge oneoo...oo erigerok, sayangee. In your uncles' houses tweets of Kimagi bird are heard, dear.

\section{(lendawi \#6)}

(5) From the living level: flora (e.g. weeds and grass). Most people in the Papuan moutain range are farmers. They, therefore, talk a lot about their gardens and about weeds in the gardens. They use weeds as metaphor for something not being taken care of, or something being left and not being nourished, and of other similar ideas, not in the sense Shakespeare uses them in his Richard II, for example. The following quotes examplify this from lendawi \#3 and \#4. In each case, there is a woman lamenting her father who has just died. She has to use these images because these are the images she is familiar with.

Nogoba wae kagalip loge yime kalir loge yinduak ooo

Father.... the place where you usually worked, weeds are growing

(lendawi \#3)

Nogoba kar mengenom kagalip loge iriga iduwak ooo

Father ... the weeds in your place grow thick

(lendawi \# 4)

\section{Conclusion}

The conclusions that can be drawn are that the lendawi generally function as eulogies or soliloquies, these functions are (1) for lamenting a dead person which are more often found because deaths more often happen and since these are final goodbyes; (2) for thanking people contributing something in an event, e.g. an adat event is something that is more planned and so may be predicted; (3) for saying goodbye to a newly wed girl to follow her husband, or a family member to go to a foreign land for certain purposes, this is also something that is more planned and may be predicted; (4) for welcoming a relative or family member from other foreign lands, etc., events like these ones cannot be predicted and therefore not very often take place; (5) for remembering a family member who is already dead or in a foreign land; this type is more personal and so may not not occur very often; (6) when meeting a person who 
resembles a family member already dead or far away; this ones may also take place rarely since kesempatan like these may be said to be very rare; (7) for remembering a person in a foreign land when looking at his or her picture(s) at home; these are also personal, and therefore, are difficult to be found; (8) for visiting a sick relative or friend; these one are also difficult to find since people from the mountains are not sick often; when they come down to the cities and get sick, they may want to go back to the mountains, and there they get well soon enough.

From Halley's semantic field, the lendawi show that most metaphorical expressions are in the level of (a) being e.g. sadness in the lamentation for the dead; (b) substance like clouds, rain, (c) terrestrial like mountains (mount Tari, Donggi and Konda rivers, (d) living like weeds and grass, (e) animate like birds (the birds kimagi, welem).

\section{References}

[1] Chink, M.K.L; Halley, M.C \& Lunsford, R.F. 1980. Linguistic Perspective on Literature. London: Routledge \& Kegan Paul, Ltd.

[2] Descola, P. 1986. La Nature Domestique: Symbolism et Praxis dans l'Ecologie des Achuar. Paris: Editions des Sciences de L'Homme.

[3] Finnegan, Ruth. 1977. Oral Poetry. London: Cambridge University Press.1991. Oral Traditions and the Verbal Arts. New York: Routledge.

[4] Kövecses, Zoltán. 2015. Where Metaphors Come From. New York: Oxford University Press

[5] Mourner, Kathleen \& Rausch, Ralph. 1991. NTC's Dictionary of Literary Terms. Lincolnwood (Chicago): National Textbook Company.

[6] Muller, Karl. 2008. Introducing Papua. Jakarta: Daisy World Books

[7] Purba, Theodorus; Warwer, Onesimus \& Fatubun, Reimundus. 1993. Fonologi Bahasa Dani Barat. Jakarta: Pusat Bahasa.

[8] Purba, Theodorus; Warwer, Onesimus \& Fatubun, Reimundus. 1997. Sintaksis Bahasa Dani Barat. Jakarta: Pusat Bahasa.

[9] Shanon B. 2002. The Antipodes of the Mind: Charting the Phenomenology of the Ayahuasca Experience, draft manuscript submitted for publication.

[10] Townsley G. 2001. Twisted Language, in Shamans Through Time: 500 Years on the Path to Knowledge, Narby J. and Huxley F. (Eds.). London: Thames and Hudson, pp. 263-271.

[11] Wahab, A. 1991. Isu Linguistik Pengajaran Bahasa dan Sastra. Surabaya: Airlangga University Press.

[12] Yikwa, Pemius. 2018. Lendawi (the Lanny Tribe Lamentation): Its Structure, Types, and Socio-cultural Values. Unpublished Master's Thesis. Jayapura: PBS, FKIP, Universitas Cenderawasih. 